\title{
Upgradation of High Sulfur NE Region Indian Coals by Pyrolysis in Presence of Hydrogen
}

\author{
Abdul Ali, N.K. Srivastava, S.K. Srivastava*, R.N. Goswami, R.S. Yadav and S.K. Hazra \\ Central Institute of Mining and Fuel Research, Digwadih Campus, P.O. FRI, Dhanbad-828108, Jharkhand, India
}

\begin{abstract}
In order to utilize high sulfur (3-6\%) coals in various industries which otherwise cannot be utilized directly or even as a blend, studies on pyrolysis of four high sulfur NE regions Indian coals viz. 60ft Tikak, 20ft Tikak, Surupi and Bapung coal from Makum Coalfields of Meghalaya in presence of hydrogen were carried out at $900^{\circ} \mathrm{C}$. The steam was generated by heating waste water followed by its super heating in the steam zone at a temperature of $400 \pm 5^{\circ} \mathrm{C}$. Hydrogen was produced from this super heated steam, copper-iron scrap reaction at $900^{\circ} \mathrm{C}$ in the promoter zone. This hydrogen was passed into reaction zone where high sulfur coal was kept at $900 \pm 5^{\circ} \mathrm{C}$. It was found that a reduction of about $58.7-91.1 \%$ in organic sulfur and $75.7-93.8 \%$ in inorganic sulfur (pyrites + sulfates) leading to total sulfur reduction from 68.6 $90.2 \%$ was achieved. After reduction in sulfur on pyrolysis, the low sulfur coke/char thus formed can be used directly as such in case where the coke/char has about $1 \%$ sulfur or the same may be used as a blend with low sulfur coke/char in different industries giving value addition to the coal.
\end{abstract}

Keywords: NE region coal, pyrolysis, hydrogen, coke/char, sulfur removal.

\section{INTRODUCTION}

Indian coals from north eastern region possess high sulfur content [1-2] varying from $3-6 \%$ in general with 75 $90 \%$ of it is in the form of organic sulfur, perhydrous and caking in nature, yields high quantity of tar on carbonization (double the quantity of tar produced from same rank of coal from other regions), high fluidity, 5-8\% inherent ash, oxygen+sulfur on dry mineral matter free basis practically equals to the oxygen content of same rank of coal from other regions, i.e. part of the oxygen is substituted by sulfur, etc. This coal is mostly being used in steel (by blending), sponge iron industries [3]. The pyritic sulfur present in NE coals is highly disseminated in organic matrix of coal [4]. It is well known [1-3] that presence of high sulfur in NE region coals is detrimental [5-7] with respect to quality of the products from above industries. The sulfate sulfur can be removed by beneficiation and other cleaning methods [8-9]. The removal of highly disseminated pyritic sulfur and organic sulfur from high sulfur NE coals can be made through various chemical and microbial methods. The microbial process is slow and not very effective in removing all types of organic sulfur using selective bacteria [8-10]. Various types of organic sulfur functional groups viz. thiol, disulphide, thioether, thioketone and thiophene are present in high sulfur NE region coal depending on the environmental conditions of coal formation [11-13]. When this coal was pyrolysed, the thioketonic and thiophenic sulfur is converted into condensed thiophenic structure where the reagents cannot enter to react with sulfur. Hence the removal of organic sulfur from $\mathrm{NE}$ coals is very difficult. Under the circumstances, only the chemical methods can reduce the

*Address correspondence to this author at the Central Institute of Mining and Fuel Research, Digwadih Campus, P.O. FRI, Dhanbad-828108, Jharkhand, India; Tel: 0326-2388362; Fax: 0326-2388360;

E-mail: sukusri1@rediffmail.com organic sulfur present in such coals as well as remove the highly disseminated pyritic sulfur (of course by oxidizing techniques to take out sulfur in water soluble form) by chemical means. Several attempts have been made in the past to obtain low sulfur char/coke from high sulfur coals [14-18] such as desulfurization of high sulfur coal with various gases (hydrogen, coal gas, steam, water gas) to obtain low sulfur char. The efficiency of sulfur removal by the reducing gases has been found to be much greater in the case of hydrogen compared to other gases [19]. About 72-80 $\%$ removal of sulfur has been reported by desulfurization with hydrogen in earlier investigations in India [19]. Hence sulfur contents has to be reduced by desulfurizing the high sulfur NE region coals to a level where it can be used directly or as a blend to suit the above industries. Now a day's even cokes are being blended. Since oxidizing methods of desulfurization destroys the caking properties of caking/coking coal, reducing methods of desulfurization has to be tried. In this case hydrogen is the reagent to take out sulfur as hydrogen sulfide but cost of hydrogen is exhorbitantly high. It has to be produced at a cheaper cost and then utilized to make the total process cost effective. The evolution of hydrogen in the present process is very well known and it is produced by the reaction between super heated steam and waste materials like iron/copper scraps. Thus the present paper deals with the production of hydrogen from waste material followed by its reaction with high sulfur NE region coals to produce low sulfur coke/char which can be either directly used or utilized as a blend in different industries. The results thus obtained by carrying out the above experiments formed the basis of this paper.

\section{MATERIALS AND METHODS}

\subsection{Coal Samples}

The high sulfur coal samples from North Eastern region of India were collected from four different coalfields viz. 
$60 \mathrm{ft}$ Tikak, Surpi, Bapung and 20ft Tikak. The collected coal samples were ground to size $\mathrm{x} 212 \mu$ before use. The samples were characterized in terms of proximate analysis such as percentage of moisture, ash, volatile matter and fixed carbon [20], ultimate analysis like carbon, hydrogen, nitrogen, sulfur and oxygen on dmmf basis [21] and calorific value (CV) following the methods described in Indian Standard Methods (IS:1350 (Part-II)-1969) [22]. The estimation of total sulfur was made using ESCHKA Method (IS:1350Part-III-1969) [23]. Sulfur distribution was also determined (IS:1350-Part-III-1969) [23].

\subsection{Experimental Setup}

The complete experimental setup is shown in Fig. (1). It is basically comprised of a steam generation unit, a silica reactor, a tubular furnace and a series of Ammonical Cadmium Chloride (2\%) solution containing bubblers. The steam is generated by heating water taken in a round bottom flask placed over an electrical heater. The silica reactor (length $940 \mathrm{~mm}$, internal diameter $21 \mathrm{~mm}$ and outer diameter $23 \mathrm{~mm}$ ) consist of three chambers viz. steam zone, promoter zone and reaction zone. The steam zone consists of $170 \mathrm{~mm}$ length of reactor from the steam feeding end which is attached with connecting tube to the round bottom flask. This zone is preheated and maintained at a temperature of $400 \pm 5^{\circ} \mathrm{C}$. The promoter zone (length $250 \mathrm{~mm}$ ) contain turnings of $\mathrm{Cu}$ and $\mathrm{Fe}$ scraps (ratio 1:9 respectively), remained confined in the middle region of the reactor and is well separated by fire wool insulation packing $(20 \mathrm{~mm}$ on either side). This zone is preheated and maintained at a temperature of $900 \pm 5^{\circ} \mathrm{C}$. The reaction zone (length $200 \mathrm{~mm}$ ) lies after the promoter zone where the processed $\mathrm{x} 212 \mu$ size coal samples were taken. This zone is preheated and maintained at a temperature of $900 \pm 5^{\circ} \mathrm{C}$. The reaction was allowed for one hour at this temperature. The total reactor system was placed in a tubular furnace (tube bore $37.5 \mathrm{~mm}$ ) made up of silliminite (alumino-silicate powder) having furnace length $650 \mathrm{~mm}$, outer diameter $250 \mathrm{~mm}$ and internal diameter $40 \mathrm{~mm}$. The furnace is fitted with two rollers to move freely on rail track assembled in a rectangular cabin. The entire set up is supported by a mild steel frame (length $750 \mathrm{~mm}$, width $325 \mathrm{~mm}$ and depth $325 \mathrm{~mm}$ ). Three chrome aluminium thermo couples were used to measure the temperature of three zones. Digital temperature indicators were used with multi point switch and three regulators to control the temperatures of the three zones as specified above. A tar catcher was attached with silica reactor which was kept in a beaker containing ice, and a series of Ammonical Cadmium Chloride (2\%) solution bubblers have been set up in order to arrest $\mathrm{H}_{2} \mathrm{~S}$ released during the experiment.

\subsection{Experimental Procedure}

At the outset, the reactor (silica tube) was packed with fire wool at places as described above followed by filling up of $10 \mathrm{~g}$ of $\mathrm{Cu}+\mathrm{Fe}$ scraps (mixture ratio: 1:9) in the promoter zone. A processed $\times 212 \mu$ size coal sample was placed in the reaction zone and closed at both the ends. The round bottom flask containing waste water was then heated and the steam thus produced was passed into the steam zone

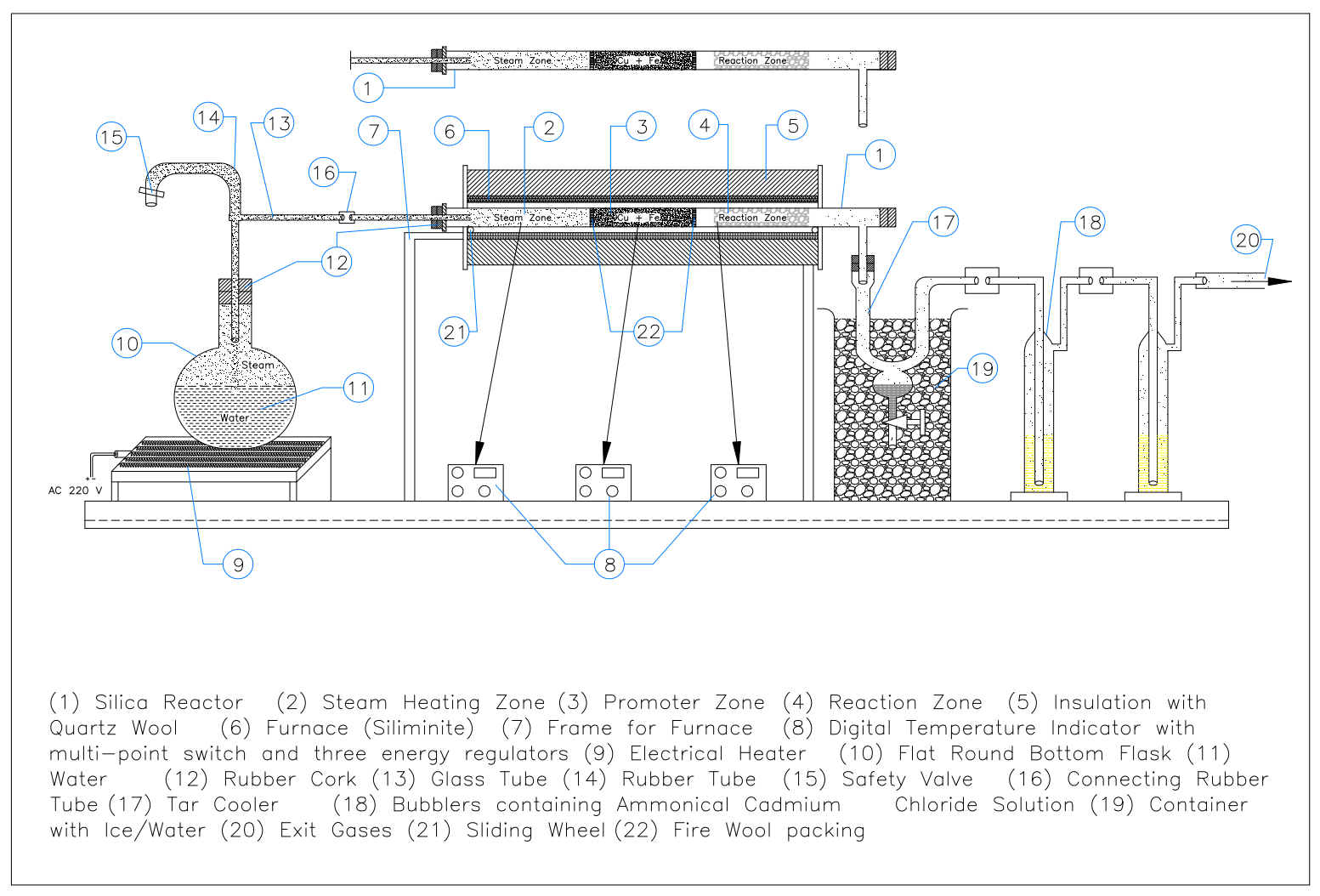

Fig. (1). Apparatus for removal of sulfur from high sulfur coals. 
maintained at a temperature of $400 \pm 5^{\circ} \mathrm{C}$ where it was converted into super heated steam. In the promoter zone (temperature $900 \pm 5^{\circ} \mathrm{C}$ ), the super heated steam reacts with $\mathrm{Cu}+\mathrm{Fe}$ scraps mixture to produce $\mathrm{H}_{2}$ in situ [Unpublished work to be communicated soon]. The composition of the product gas $(\mathrm{v} / \mathrm{v})$ after completion of the reaction in the promoter zone as analyzed using Sigma Gas Chromatograph (Model-8312) is: $\mathrm{CO}_{2}: 0.7 \%, \mathrm{CO}: 0.3 \%, \mathrm{CH}_{4}$ : traces, $\mathrm{O}_{2}$ : traces, $\mathrm{N}_{2}: 7.1 \%$ and $\mathrm{H}_{2}: 91.7 \%$. The hydrogen from the promoter zone was then passed into the reaction zone at $900 \pm 5^{\circ} \mathrm{C}$. The composition of product gases after completion of the reaction for one hour in this zone at $900 \pm 5^{\circ} \mathrm{C}$ after tar catcher followed by absorption of hydrogen sulfide $\left(\mathrm{H}_{2} \mathrm{~S}\right)$ produced in Ammonical Cadmium Chloride (2\%) solution to form Cadmium sulfide (yellow precipitate), is: $\mathrm{CO}_{2}: 7.9 \%$, CO: $27.8 \%, \mathrm{CH}_{4}: 2.1 \%, \mathrm{O}_{2}$ : traces, $\mathrm{N}_{2}: 2.1 \%$ and $\mathrm{H}_{2}: 60.1 \%$. The tar and liquor vapors were condensed in the tar catcher. After one hour the furnace was switched off to get the system cooled down to room temperature. The reactor was then taken out and the product coke/char was discharged and collected for further analysis. The char/coke thus collected is weighed and further processed for proximate analysis, ultimate analysis, $\mathrm{CV}$ and total sulfur estimation by
ESCHKA method [23] and also for sulfur distribution [21]. The results of total sulfur, sulfur distribution, proximate and ultimate analyses of raw coals and char/coke are provided in Tables 1-4. Percent reduction of sulfur after desulfurization is depicted in Table 4.

\subsection{Other Materials}

The chemicals/materials used during the experiment/analysis were of following grades: Dried cadmium chloride (L.R. Qualigens), light calcined magnesium oxide (Merck), anhydrous sodium carbonate (A.R., Ranken), $\mathrm{HCl}$ (L.R. grade), $\mathrm{HNO}_{3}$ (L.R. grade), $\mathrm{BaCl}_{2}$ (GR), methyl red (Ranbaxy), ammonium hydroxide (EXCELAR), rectified spirit, silver nitrate (Qualigens), porcelain crucible (Berlin), Whattman filter paper, distilled water, etc.

\section{BASIC PRINCIPLES OF REACTION IN DIFFERENT ZONES OF THE REACTOR}

\subsection{In Promoter Zone}

In the promoter zone, the super heated steam combined with iron $(\mathrm{Fe})$ and copper $(\mathrm{Cu})$ scraps mixture at a temperature of $900 \pm 5^{\circ} \mathrm{C}$ wherein the oxides of iron and

Table.1. Proximate and Ultimate Analyses of High Sulfur NE Coal (As Received Basis)

\begin{tabular}{|c|c|c|c|c|c|c|c|c|c|c|}
\hline \multirow{2}{*}{ Coal } & \multicolumn{4}{|c|}{ Proximate Analysis (\% wt) } & \multirow{2}{*}{ CV Kcal $/ \mathbf{k g}$} & \multicolumn{5}{|c|}{ Ultimate Analysis (\%) } \\
\hline & M & $\mathbf{A}$ & VM & FC & & $\mathbf{C}$ & $\mathbf{H}$ & $\mathbf{N}$ & Org. S & O (by Diff.) \\
\hline $60 \mathrm{ft} \mathrm{Tikak/Makum}$ & 4.2 & 13.2 & 37.5 & 45.1 & 6805 & 68.7 & 4.7 & 1.3 & 3.24 & 4.66 \\
\hline Surupi & 2.3 & 10.2 & 37.2 & 50.3 & 7326 & 73.9 & 4.9 & 1.3 & 3.98 & 3.42 \\
\hline Bapung & 1.4 & 7.0 & 43.3 & 48.3 & 7723 & 76.7 & 5.4 & 1.0 & 3.55 & 4.95 \\
\hline $20 \mathrm{ft}$ Tikak & 4.5 & 5.6 & 36.9 & 53.0 & 7424 & 75.2 & 5.0 & 1.5 & 5.39 & 2.87 \\
\hline
\end{tabular}

M- Moisture, A- Ash, VM- Volatile matter, FC- Fixed carbon, CV-Calorific value, Org. S-Organic sulfur, Oxygen: by difference.

Table.2. Proximate and Ultimate Analyses of High Sulfur NE Coal (Dry Mineral Matter Free Basis)

\begin{tabular}{|c|c|c|c|c|c|c|c|}
\hline \multirow{2}{*}{ Coal } & \multicolumn{2}{|c|}{ Proximate Analysis (\% wt) } & \multicolumn{4}{|c|}{ Ultimate Analysis (\%) } \\
\cline { 2 - 9 } & VM & FC & C & H & N & Org. S & O (by Diff.) \\
\hline \hline $60 \mathrm{ft} \mathrm{Tikak/Makum}$ & 42.5 & 57.5 & 83.2 & 5.7 & 1.6 & 4.12 & 5.38 \\
\hline Surupi & 41.2 & 58.8 & 84.5 & 5.6 & 1.5 & 4.65 & 3.75 \\
\hline Bapung & 46.2 & 53.8 & 83.7 & 5.9 & 1.1 & 3.95 & 5.35 \\
\hline $20 \mathrm{ft}$ Tikak & 40.2 & 59.8 & 83.7 & 5.6 & 1.7 & 6.08 & 2.92 \\
\hline
\end{tabular}

Unit Coal Basis: $100-(1.1 \mathrm{x}$ ash $+\mathrm{M}+0.55 \mathrm{~S}$ pyr $+2.5 \mathrm{x} \mathrm{S}$ sul).

VM- Volatile matter, FC- Fixed carbon, CV-Calorific value, Org. S-Organic sulfur, Oxygen: by difference.

Table.3. Proximate and Ultimate Analyses of Char/Coke After Desulfurization (As Received Basis)

\begin{tabular}{|c|c|c|c|c|c|c|c|c|c|c|}
\hline \multirow{2}{*}{ Coal } & \multicolumn{5}{|c|}{ Proximate Analysis (\% wt) } & \multicolumn{5}{|c|}{ Ultimate Analysis (\%) } \\
\hline & $\mathbf{M}$ & $\mathbf{A}$ & VM & FC & CV Kcal/kg & $\mathbf{C}$ & $\mathbf{H}$ & $\mathbf{N}$ & Org. S & O* (by Diff.) \\
\hline $60 \mathrm{ft}$ Tikak/Makum & 6.8 & 22.0 & 3.5 & 67.7 & 5682 & 65.6 & 2.6 & 2.2 & 2.32 & - \\
\hline Surupi & 5.8 & 29.2 & 4.4 & 60.6 & 5182 & 59.8 & 2.5 & 1.9 & 1.68 & - \\
\hline Bapung & 7.5 & 25.3 & 1.3 & 65.9 & 5371 & 62.2 & 2.3 & 2.2 & 1.22 & - \\
\hline $20 \mathrm{ft} \mathrm{Tikak}$ & 14.8 & 9.1 & 5.2 & 70.9 & 6067 & 66.5 & 2.6 & 2.5 & 1.17 & 3.33 \\
\hline
\end{tabular}


Table 4. Sulfur Distribution of Coal and Char/Coke

\begin{tabular}{|c|c|c|c|c|c|c|c|c|}
\hline \multirow{3}{*}{ Coal } & \multicolumn{8}{|c|}{ Sulfur Distribution (\%) } \\
\hline & \multicolumn{4}{|c|}{ Coal } & \multicolumn{4}{|c|}{ Char/coke } \\
\hline & S pyr & S-sul & S-org & TS & S pyr* & S-sul & S-org & TS \\
\hline $60 \mathrm{ft}$ Tikak/Makum & 0.08 & 1.2 & 3.24 & 4.52 & $0.04(0.08)$ & 0.10 & 2.36 & 2.50 \\
\hline Surupi & 0.46 & 0.35 & 3.98 & 4.79 & $0.09(0.18)$ & 0.16 & 1.77 & 2.02 \\
\hline Bapung & 0.80 & 0.34 & 3.55 & 4.69 & $0.06(0.11)$ & 0.09 & 1.27 & 1.42 \\
\hline $20 \mathrm{ft} \mathrm{Tikak}$ & 0.02 & 0.33 & 5.39 & 5.74 & $0.08(0.15)$ & 0.14 & 1.24 & 1.46 \\
\hline
\end{tabular}

S pyr-Pyritic sulfur, S sul- Sulfate sulfur, $\mathrm{S}$ org- Organic sulfur, TS- Total Sulfur

* In fact at $900^{\circ} \mathrm{C}$, no $\mathrm{FeS}_{2}$ is present. It should be sulphide as per the reaction $\mathrm{FeS}_{2}=\mathrm{FeS}+\mathrm{S}$. Since in BIS method, iron is estimated and not the sulfur directly, their value will be reduced minimum by $50 \%$ which are reported here, whereas the experimental value is given in parenthesis.

copper were formed along with the production of hydrogen [24].

$$
\begin{aligned}
\underset{\text { (Super heated steam) }}{3 \mathrm{H}_{2} \mathrm{O}}+\underset{\text { (Promoter) }}{2 \mathrm{Fe}} \underset{\text { (Super heated steam) }}{\mathrm{H}_{2} \mathrm{O}}+\underset{\text { (Promoter) }}{\mathrm{Cu}} \longrightarrow \mathrm{Fe}_{2} \mathrm{O}_{3}+3 \mathrm{H}_{2} & \longrightarrow \mathrm{CuO}+\mathrm{H}_{2}
\end{aligned}
$$

\subsection{In Reaction Zone}

In reaction zone, the produced hydrogen (2) combines with sulfur in coal and forms $\mathrm{H}_{2} \mathrm{~S}$.

$$
\underset{\text { (In situ generation) }}{\mathrm{H}_{2}}+\underset{\text { (From Coal sample) }}{\mathrm{S}} \longrightarrow \mathrm{H}_{2} \mathrm{~S}+\text { coal }
$$

The remaining un-reacted steam react s with red hot coke $\left(900^{\circ} \mathrm{C}\right)$ and forms water gas

$$
\underset{\text { (Unreacted Steam) }}{4 \mathrm{H}_{2} \mathrm{O}}+\underset{\text { (Red hot coke) }}{3 \mathrm{C}} \longrightarrow \mathrm{CO}_{2}+2 \mathrm{CO}+4 \mathrm{H}_{2}
$$

\subsection{In Ammonical Cadmium Chloride (2\%) containing bubblers}

$\mathrm{H}_{2} \mathrm{~S}$ reacted with Ammonical cadmium chloride solution (2\%) to form yellow precipitate of Cadmium sulfide.

$$
\mathrm{CdCl}_{2}+\mathrm{H}_{2} \mathrm{~S} \longrightarrow \mathrm{CdS}+2 \mathrm{HCl}
$$

\subsection{Residual Air}

The residual air in the reactor system contains small amount of nitrogen and one fourth of its quantity as oxygen. This oxygen reacts with carbon of coal to yield carbon mono oxide as follows:

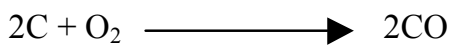

\section{RESULTS AND DISCUSSION}

The proximate analysis, ultimate analysis and sulfur distribution of the coal samples collected from different coalfields of NE region and desulfurized coke/char are presented in Tables 1-4.

Amongst the four coal samples studied (as received basis), the moisture content varied from $1.4 \%$ to $4.5 \%$ while the ash content varied in the range from 5.6-13.2\%, volatile matter (VM) from 36.9 to $43.3 \%$, and fixed carbon (FC) from 45.1 to $53.0 \%$. The calorific value of the Bapung coal is higher $(7723 \mathrm{Kcal} / \mathrm{kg})$ than the other three coals (CV: $6805-7424 \mathrm{Kcal} / \mathrm{kg}$ ), which is inversely proportional to the percentage of moisture and ash content (Table 1). Similarly the ultimate analyses $(\mathrm{C}, \mathrm{H}, \mathrm{N}$, Org. S and $\mathrm{O})$ of the coals varied from $68.7-76.7 \%$ for $\mathrm{C}$, from $4.7-5.4 \%$ for $\mathrm{H}$, from $1.0-1.5 \%$ for $\mathrm{N}$ from $3.24 \%-5.39 \%$ for organic sulfur and from $2.87-4.95 \%$ for $\mathrm{O}$. Organic sulfur content is reasonably higher (3.0-5.4\%) as compared to other Indian coals. This is primarily because part of the oxygen in NE region coals is substituted by sulfur. Similarly proximate and ultimate analyses (Table 2) on dry mineral matter free basis (dmmf basis) showed that amongst the raw coals, the volatile matter varied from 41.2 (minimum) of Surupi to $46.2 \%$ (maximum) of Bapung coal, fixed carbon from 53.8-59.8\%, calorific value from $8239-8431 \mathrm{Kcal} / \mathrm{kg}$. From the ultimate analyses, the values ranged from $83.2 \%-84.5 \%$ for $\mathrm{C}, 5.6 \%$ $5.9 \%$ for $\mathrm{H}, 1.1 \%-1.7 \%$ for $\mathrm{N}, 3.95 \%-6.08 \%$ for organic $\mathrm{S}$ and $2.92 \%-5.38 \%$ for $\mathrm{O}$ (by difference). After removal of ash and moisture the calorific value of the coal is significantly enhanced with simultaneous increase in quality of coal.

Table 4 describes the distribution of different forms of sulfur in the studied coals. The pyritic sulfur varied from $0.02 \%$ to $0.80 \%$, sulfate sulfur from $0.33 \%$ to $1.2 \%$, organic sulfur from $3.24 \%$ to $5.39 \%$ and total sulfur from $4.52 \%$ $5.74 \%$. The contribution of organic sulfur is quite high (72$94 \%$ ) as compared to pyritic and sulfate sulfur (inorganic form). This is also in agreement with already reported results $[2,3,13]$.

After desulfurization, the coal is converted into char/coke. It is observed from Table $\mathbf{3}$ that the moisture content of char/coke is found to be higher/much higher as compared to the respective raw coals on heat treatment in absence of air. The increase in moisture content in the present study is probably ascribable to the super heated steam reaction which activates the carbonized product (char/coke) and significantly changes the surface characteristics including porosity $[25,26]$. Under such conditions new pores are generated, blind pores become open, creation of functional group due to steam activation, enhancement in internal surface area, etc attracting moisture. The calorific value of char/coke has decreased after desulfurization. This can be attributed towards the removal of volatile matter from coal. On comparison of Table 1 with Table 3, it is noticed that the ash content and fixed carbon of char/coke have increased and varied in the range 9.1-29.2\% and $60.6-70.9 \%$, respectively. This can also be explained on the basis of removal of volatile matter along with moisture during heat treatment of raw coal resulting in respective 
enhancement of ash and fixed carbon content of coke/char. The volatile matter (VM) is found to reduce in the range 85$97 \%$. Comparing the ultimate analysis of raw coal and coke/char provided in Tables $\mathbf{1}$ and $\mathbf{3}$, it is observed that the carbon, hydrogen, organic sulfur and oxygen contents were found to decrease while the nitrogen percentage increased. As a result, the total sulfur content drastically reduced. A careful examination of the sulfur distribution figures of raw coal and that of coke/char reveals that pyritic, sulfate and organic sulfur contents have remarkably decreased (Table 4). The respective figures in the char/coke varied in the range $0.04-0.09 \%$ for pyritic-S, $0.09-0.16 \%$ for sulfate-S, and $1.24-$ $2.36 \%$ for organic-S. The total sulfur is reduced in the range $1.42-2.50 \%$ from the raw coal $(4.69-5.74 \%)$. Since the coal is sub-bituminous in nature, a lot of functional groups like $\mathrm{COOH},-\mathrm{OH},-\mathrm{CH}_{3},-\mathrm{SH},-\mathrm{S}-,-\mathrm{S}-\mathrm{S}-$, etc. are expected to be eliminated during pyrolysis resulting in decrease in hydrogen, sulfur and oxygen contents. There is practically no loss of nitrogen on heating and the loss of carbon in comparison to loss of oxygen, sulfur and hydrogen is much less resulting in overall enhancement of carbon content.

From Fig. (2a), it is observed that among the four coals used $(10 \mathrm{~g})$ for desulfurization, inorganic sulfur was minimum $(0.35 \%)$ in $20 \mathrm{ft}$ Tikak coal whereas it was maximum $(1.28 \%)$ in $60 \mathrm{ft}$ Tikak coal. The percent organic sulfur ranged between 3.24 to $5.39 \%$ with minimum in $60 \mathrm{ft}$ Tikak coal and maximum in $20 \mathrm{ft}$ Tikak coal. Similar to the organic sulfur content, the total sulfur content is also highest $(5.74 \%)$ in $20 \mathrm{ft}$ Tikak coal and lowest $(4.52 \%)$ in $60 \mathrm{ft}$ Tikak coal. In $60 \mathrm{ft}$ Tikak coal, the inorganic (pyrite+sulfate) sulfur content is much lower as compared to the organic and total sulfur contents. This may probably be due to the fact that pyrite is not a necessary intermediate to the formation of organic sulfur in coal; however elemental sulfur or polysulfides may be the source of some thiophenes [12]. Yurovskii [27] also pointed out that when pyrite is formed from ferric sulfate and $\mathrm{H}_{2} \mathrm{~S}$, elemental sulfur is released which can react with coal. The yield of char of different coals used varied in the range from 3.3-5.67 $\mathrm{g}$ from $10 \mathrm{~g}$ of original coal as in Fig. (2b), which shows 33-56\% yield of char/coke after desulfurization. On comparison of Fig. (2a) with Fig. (2c), it was found that overall total sulfur content in char/coke was in the range $1.42-2.50 \%$ whereas in raw coal it varied from $4.52-5.74 \%$. Thus $68.6-90.2 \%$ reduction in total sulfur is observed from Fig. (2d). Similarly inorganic sulfur varied from $0.14-0.25 \%$ in char/coke resulting in the reduction of inorganic sulfur from $75.67-93.75 \%$. Among the two inorganic components, the sulfate sulfur of raw coal gets reduced in presence of steam and the sulfur is converted in the gaseous form while the pyritic sulfur content reduced by eliminating sulfur as hydrogen sulfide except in the case of $20 \mathrm{ft}$ Tikak coal. This increase may be due to the transformation of other forms of sulfur to the pyrite sulfur during the process of desulfurization [18, 28-29]. A reduction of $75.67-93.75 \%$ in inorganic sulfur is mainly due to the loss in sulfate sulfur as is evident from Fig. (2). The amount of sulfur reduction in the other two coals (Surupi and Bapung coal) are observed to be $1.77 \%$ and $1.27 \%$ in organic sulfur leading to $85.32 \%$ and $81.39 \%$ removal, respectively. These two coals show a promising decrease in both pyritic and sulfate sulfur (inorganic) in char/coke resulting in an overall reduction of $89.8 \%$ and
$93.15 \%$, respectively. It is difficult to provide any specific reason for the variation in the reduction of organic sulfur and its disposition pattern. It is known [13] that high sulfur NE coals have thiol, disulphide, thioether, thioketone and thiophene as organic sulfur functional groups. Out of which the first three is removed easily while the last two is difficult to remove. It is also known that the last two groups are more in NE region coal which is situated at greater depth. Hence the results on order of reduction of organic sulfur presented in Fig. (2d) for the four coals can be easily explained. Borah et al. [2] and Calkins [12] have expressed that due to unknown structure of sulfur compounds associated with the coal molecule, exact explanation for quantum of organic sulfur removal cannot be provided. Kar et al. [1] has also mentioned that the probable type of organic sulfur compound which undergoes the desulfurization reaction is not known. The variation in the extent of desulfurization of these high sulfur coals may be due to the different disposition pattern of organic sulfur in the coal structure [13] (Mercaptan, Thiol, Disulphide, Thioether, Thiophenes and Thioketone). Kumar and Srivastava [13] have established the disposition pattern of sulfur in Assam coal of North Eastern region of India, where they have found that five types of organic functional groups viz. disulphide, thiol, thioether, thiophene and thioketone are present in Assam coals. - $\mathrm{SH}$ group is present on the periphery of aromatic ring, $-\mathrm{S}$ - and $-\mathrm{S}-\mathrm{S}$ - groups are present in between two units of coal but thiophene and thioketone groups are present in the aromatic ring or in between two aromatic rings side by side of thiophenic ring. The last two on heat treatment is converted into condensed thiophenic structure. Thus access of hydrogen to this sulfur becomes most difficult. The first three organic sulfur functional groups can easily be approached by hydrogen to yield hydrogen sulfide.

In case of $60 \mathrm{ft}$ Tikak coal, the highest reduction of $93.75 \%$ was observed in inorganic sulfur, whereas $20 \mathrm{ft}$. Tikak Coal showed lowest reduction of $75.67 \%$. The probable reason for the lowest reduction in the case of $20 \mathrm{ft}$. Tikak Coal is mainly due to the conversion of secondary sulfur into pyritic sulfur during the process of pyrolysis. As a result the pyritic sulfur has increased from $0.02 \%$ to $0.08 \%$ (Table 4) limiting the overall reduction in inorganic sulfur in the desulfurised char/coke. As such the removal of inorganic sulfur depends on the removal of pyritic as well as sulfate sulfur present in the coal and the rate of transformation of secondary sulfur to the pyritic sulfur during the process of pyrolysis [30-31].

The study revealed that all the four high sulfur coal samples from NE region of India demonstrated a remarkable decline in organic sulfur content on its in situ hydrogen treatment at a temperature of $900^{\circ} \mathrm{C}$ and a significant loss in inorganic sulfur $[3,4,12,32-33]$. It implies that this method of desulfurization not only removes the organic sulfur (58.7$91.1 \%$ ) but reduces the inorganic sulfur also to a great extent (75.67-93.75\%). Simultaneously the volatile matter has been drastically reduced in the range 1.9-6.8 \% from 40.7-46.6\% level on unit coal basis whereas the ash content and moisture content have proportionately increased. This is due to the removal of volatile matter and increase in porosity, internal surface area, etc. $[34,35]$. The results are in agreement with Singh et al. [36] who did the experiments on carbonization of raw coal as well as blended coal at high temperature. The 


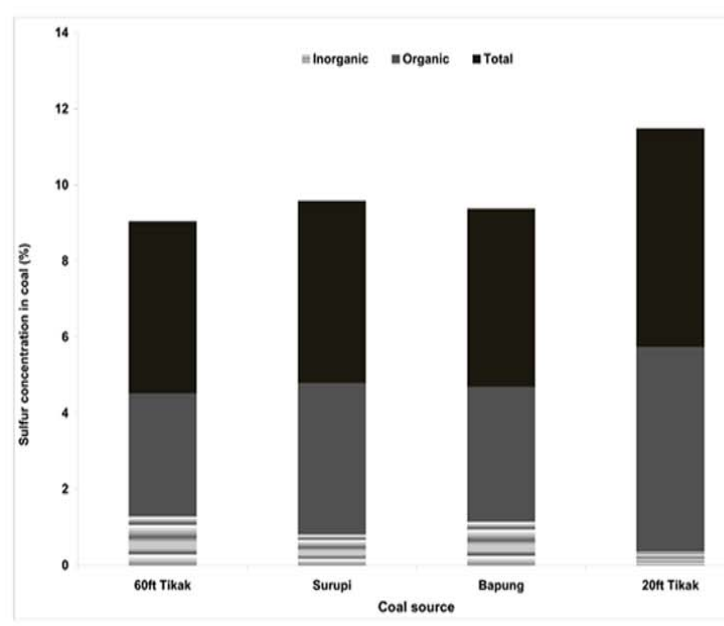

(a)

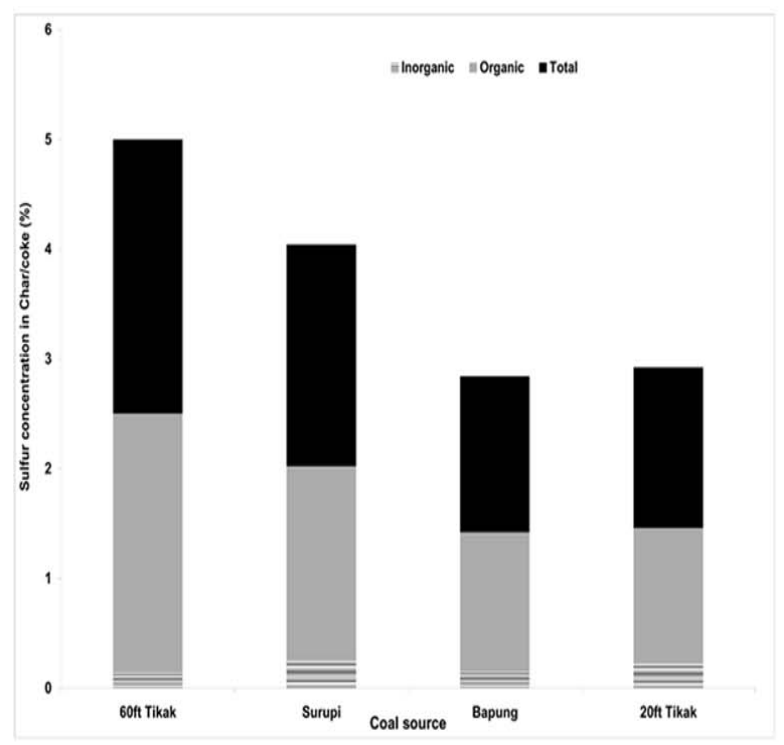

(c)

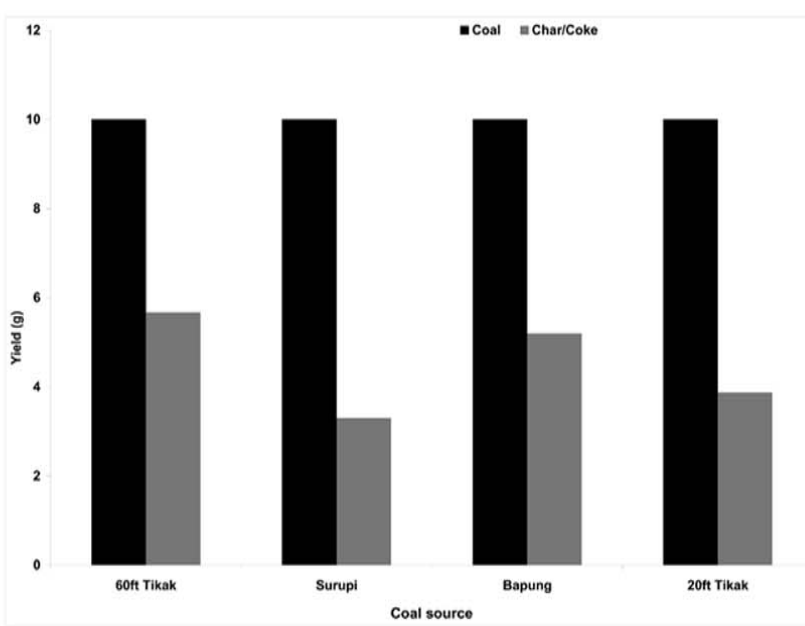

(b)

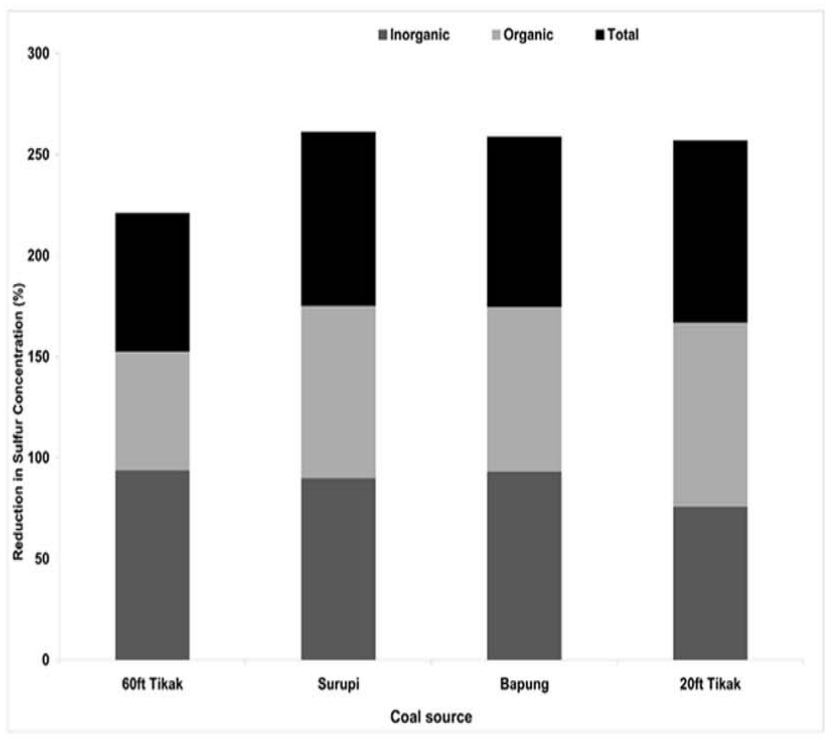

(d)

Fig. (2). (a) concentration of sulfur forms in coal used; (b) yield of char/coke; (c) concentration of sulfur in char/coke; and (d) reduction in sulfur concentration.

other characteristics of char/coke such as carbon content varied in the range $88.5-92 \%$ with $\mathrm{CV} 7973-7992 \mathrm{Kcal} / \mathrm{Kg}$ suggests that the low sulfur char/coke could be used multipurpose as a blend with low sulfur coke, as such in sponge iron, cement, etc. industries or as a high surface area adsorbent, active carbon, making briquette, etc [34]. As such, the removal of organic as well as inorganic sulfur could be obtained simultaneously through this desulfurization method in order to produce a low sulfur carbonized product from high sulfur NE region coals in an eco-friendly manner. It is worth mentioning here that during the experiment waste materials may not react with super heated steam sufficiently in the promoter zone, and in the reaction zone hydrogen may not react with coal sufficiently because the steam entered in the tubular reactor has no pressure and there is no carrier gas. The conditions may be improved when the promoter zone and reactor zone would have been vertical.

\section{CONCLUSIONS}

From the foregoing discussions, it can be concluded that:

1. The production of hydrogen during this process is based on simple mechanism of reactions between super heated steam and iron-copper scraps mixture.

2. The organic and total sulfur from the high sulfur NE region coals could be reduced in the range 58-90\% 
apart from appreciable reduction (75.67-93.75\%) in inorganic sulfur (pyrites + sulfates).

3. Low sulfur char/coke produced by this method could be utilized for making briquette, active carbon and can be used as a suitable blend for metallurgical purposes.

4. The process is expected to be cost effective as the components such as water, iron scraps, copper turnings used for the experimentation are cheap however further studies are required to be done in order to establish the economic viability.

\section{ACKNOWLEDGEMENTS}

The authors express their gratitude to the Director, CIMFR (Digwadih Campus), Dhanbad for permitting us to publish the paper. The co-operation rendered by Dr. L.C. Ram, Deputy Director \& Head, Environmental Management Division is gratefully acknowledged. Thanks are also due to Sri H B Moitra, Sri A P Singh, and Sri Tarun Pramanik for their help and analytical support in carrying out the various activities associated with desulfurization experiments.

\section{REFERENCES}

[1] Karr Jr. C.; Ed. Analytical Methods for Coal and Coal Products, Academic Press. New York. 1978, Vol. 1 pp. 280- 323.

[2] Borah, D.; Baruah, M. K. Electron transfer process, removal of organic sulfur from high sulfur Indian coals. Fuel, 1999, 78, 10831088.

[3] Ali, A.; Srivastava, S.K.; Haque, R. Chemical desulfurization of high sulfur coals. Fuel, 1992, 71, 835-839.

[4] Srivastava, S.K. Recovery of sulfur from very high ash fuel and fine distributed pyritic sulfur containing coal using ferric sulfate. Fuel Proc. Technol., 2003, 84, 37-46.

[5] Eliot, R. C. Coal Desulfurization Prior to Combustion, Noyes Data Corp., N.J. 1978, p. 33.

[6] Meyers, R. A. Coal Desulfurization, Marcel Dekker, New York, 1977, p. 61.

[7] Kargi, F. Microbiological coal desulfurization. Enzyme Microb. Technol., 1982, 4, 13-18.

[8] Wheelock, T.D. Chemical desulfurization-chemical and physical methods. American Chemical Society, Washington, DC, 1977.

[9] Chugh, Y.P.; Caudle, R.A. Processing and utilization of high sulfur coals. Elsevier, New York, vol. I 1985 \& vol. II 1987.

[10] Kargi, F.; Robinson, J.M. Removal of organic sulfur from bituminous coal: use of the thermophilic organism. Sulfolobus acidocaldarius. Fuel, 1986, 65, 397-399.

[11] I.E.A Coal research review in coal science: the problems of sulfur, London: Butterwoths, 1989.

[12] Calkins, W.H. The chemical forms of sulfur in coals: a review. Fuel, 1994, 73, 475-484.

[13] Kumar, A.; Srivastava, S.K. Distribution of organic sulfur in Tipang coal using temperature programmed reduction. Fuel, 1992, 71, 718-719.
[14] Uzun, D.; Özdoğan, S. Sulfur removal from original and acid treated lignites by pyrolysis. Fuel, 2006, 85, 315-322.

[15] Laughlin, K.M.; Gavin, D.G.; Reed, G. P. Coal and char nitrogen chemistry during pressurized fluidized bed combustion. Fuel, 1994, 73, 1027-1033.

[16] Hjalmarsson, A.K. NOx Control Technologies for Coal Combustion, IEACR/24, IEA Coal Research, London, 1990.

[17] Qi, Y; Li, Wen; Chen, H; Li, B. Sulfur release from coal in fluidized-bed reactor through pyrolysis and partial oxidation with low concentration of oxygen. Fuel, 2004, 83, 2189-2194.

[18] Maa, S.; Lewis C.R.; Hamrin, C.E. Jr. Sulphur transformation and removal for Western Kentucky coals. Fuel, 1975, 54, 62-69.

[19] Roy, K. K.; Basak, N.G. Removal of sulfur from high sulfur coals. J. Mines Metals Fuels, (Special) 1959, 365-370.

[20] I.S. Indian Standard Methods of test for coal and coke, 1350-Part-IProximate analysis, 1969.

[21] I.S. Indian Standard Methods of test for coal and coke, 1350-PartII- Determination of calorific value, 1969.

[22] I.S. Indian Standard Methods of test for coal and coke, 1351Ultimate analysis, 1959.

[23] I.S. Indian Standard Methods of test for coal and coke, Part-IIIDetermination of sulfur, 1969.

[24] Dutt, P.K. General and Inorganic Chemistry, Vol. I, $5^{\text {th }}$ ed.; 1975.

[25] Bansal, R.C.; Donnel, J.P.; Stoeckli, F. Active Carbons, Marcel Dekker, Inc., New York, 1988.

[26] Roy, J.; Guha, O.K. Effect of activation of lignite char on the separation of common gases by gas chromatography. Fuel Sci. Technol., 1994, 13, 89-92.

[27] Yurovskii, A.Z. Sulfur in coal, English Translation TT70-57216 US Dept of the Interior, 1974, p. 92.

[28] Baruah, M K. The theory of genesis of secondary sulfur. Fuel Proc. Technol., 1995, 45, 155-160.

[29] Baruah, M. K.; Gogoi, P. C. A new form of sulfur in coal: The discovery of an iron-sulfur coordination compound. Fuel, 1999, 77, 979-985.

[30] Altschuler, Z.S.; Schnepfe, M.M.; Silber, C.C.; Simon, F.O. Sulfur diagenesis in everglades peat and origin of pyrite in coal. Science, 1983, 221, 221-227.

[31] Senaratne, H.L.; Tobschall, Dissanayaka, C.B. Diagenesis of sulfur in a peat forming environment: a case study from Sri Lanka. Fuel, 1990, 69, 327-333.

[32] Karaca, S. Desulfurization of a Turkish lignite at various gas atmospheres by pyrolysis: effect of mineral matter. Fuel, 2003, 82, 1509-1516.

[33] Chen, H.; Li, B; Zang, B. Decomposition of pyrite and the interaction of pyrite with coal organic matrix in pyrolysis and hydropyrolysis. Fuel, 2000, 79, 1627-1631.

[34] Ahmadpour, A.; Do, D.D. The preparation of active carbons from coal by chemical and physical activation. Carbon, 1996, 34, 471479.

[35] Laine, J.; Calafat, A.; Labady, M. Preparation and characterization of activated carbons from coconut shell impregnated with phosphoric acid. Carbon, 1989, 27, 191-195.

[36] Singh, P.; Choudhary, R.; Yadav, R.S.; Banerjee, S.; Hazra, S.K. In Utilization of less/over matured inferior coal in non-recovery type of coke oven by stamping technology, Proceedings of the International Seminar on Coal Science \& Technology: Emerging global dimensions, Global Coals: 2005; (Singh, A.K.; Sen, K.; Sinha A.; Hazra, S.K., Eds.); CIMFR, Dhanbad, India, 2005; p. 218. 